\title{
RESEARCH \& DEVELOPMENT PREMIUM IN THE INDIAN EQUITY MARKET: AN EMPIRICAL STUDY
}

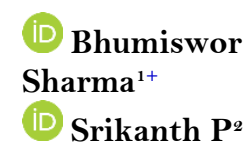

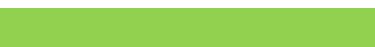

Article History

Received: 3 August 2021

Revised: 8 September 2021

Accepted: 30 September 2021

Published: 25 October 2021

\section{Keywords}

Asset pricing

$\mathrm{R} \& \mathrm{D}$ premium

Size

Value premium

Profitability

Investment

Portfolio management.

JEL Classification:

G10; G12; G14.

\begin{abstract}
${ }^{1,2}$ Christ University, Mysore Road, Kengeri Campus, Bangalore India.
'Email: bhumiswor.sharma@,res.christuniversity.in Tel: +9187480660619

Email: srikanth.p@christuniversity.in Tel: +919845418657
\end{abstract}

\section{ABSTRACT}

This article aims to investigate the research and development $(\mathrm{R} \& \mathrm{D})$ premium and explore the three most prominent asset pricing models: capital asset pricing and the three-and five-factor models (Fama \& French, 1993; 2015). The results show that India's annualized average R\&D premium is significantly higher than the existing value, market, profitability, size and investment premiums, implying that the $\mathrm{R} \& \mathrm{D}$ premium is a more significant concern for Indian investors, particularly for high R\&D firms. It was also observed that by applying the GRS test and the Fama and MacBeth (1973) two-pass procedure, the R\&D risk factor augmented the CAPM, FF3F and FF 5 F models outperforming the existing CAPM, FF3F and FF5F models, respectively. We can also report that $\mathrm{R} \& \mathrm{D}$ is, unquestionably, a priced ingredient and a critical factor in developing pricing models for developing markets such as India. The paper's conclusions add to the current literature in $\mathrm{R} \& \mathrm{D}$ and asset pricing and assist investment professionals in developing better investment and trading strategies.

Contribution/ Originality: This study is one of very few studies which have investigated the cost of traded $\mathrm{R} \& \mathrm{D}$ premium in India as a developing market, and it explores the new $\mathrm{R} \& \mathrm{D}$ risk factor for the Indian equity market using the three most prominent asset pricing models to describe portfolio monthly returns.

\section{INTRODUCTION}

Do companies with high research and development investment provide higher equity returns for their investors in emerging markets? Lev and Sougiannis (1996) first identified R\&D investment overvaluation by firms and considered a financial reward for risk as a hypothesis. This question has incited considerable interest in economics and finance literature. However, it has been shown that R\&D expenditure has a long-term effect on the future earnings and profitability of companies. According to some studies, R\&D spending may cause earnings distortion and mispricing (Chan, Lakonishok, \& Sougiannis, 2001; Lev, Sarath, \& Sougiannis, 2005). Other recent studies contend that volatility related to $\mathrm{R} \& \mathrm{D}$ investment may increase risk, causing investors to demand higher excess returns (Kim \& Park, 2020; Li, 2011; Lin \& Wang, 2016). Yu, Liu, Fung, and Leung (2020) determined that R\&D expenditure, as a form of corporate innovation, is one potential risk factor for stock returns. $\mathrm{R} \& \mathrm{D}$ expenditure is one of the significant components of corporate strategies that enhance a company's long-term profitability (Balsmeier, Fleming, \& Manso, 2017; Rubera \& Kirca, 2012; Sunder, Sunder, \& Zhang, 2017). R\&D investment is a fundamental driver of long-term growth in the economy (Wang \& Zhang, 2020). In the case of India, a recent study 
has shown that the proportion of R\&D investments has steadily increased in line with the country's GDP growth (Sinha, Mishra, \& Patel, 2019). The IMF World Economic Outlook (April 2021) shows India's nominal GDP in 2021 to be $\$ 3,050$ billion at today's price. This forecast places India as the sixth biggest economy in the world. India contributes $3.25 \%$ of the global GDP and accounts for over $16 \%$ of Asia's GDP (PPP). The World Bank shows that the 2002-19 timeframe is the best for the Indian economy, during which the country's economy expanded by $458 \%$ over 17 years. In the post-reform era, R\&D investments as a percentage of GDP expanded from $0.60 \%$ to $0.85 \%$; however, it remains significantly lower than the global average (2.25\%), and other countries such as Israel employs nearly $4.30 \%$, Korea accounts for $4.20 \%$, and Japan invests 3.30\%. The Economic Survey 2020-21 shows that India entered the top 50 innovative countries in 2020, ranking 48th out of 131 countries in the Global Innovation Index (GII). There is a need for more focus on innovation for the business sector to contribute to R\&D activities. The Economic Survey 2020 - 21 also suggested that India still needs to invest up to $2 \%$ of GDP toward R\&D investment. The Union Budget 2021-22 has given India's research and innovation ecosystems the much-needed attention. It was also discussed as one of the six key pillars of the budget under "Innovation and R\&D".

The study on R\&D investment may be a significant factor in determining the value of firms based on the underlying needs of $\mathrm{R} \& \mathrm{D}$ investment in India. $\mathrm{R} \& \mathrm{D}$ projects can improve competitiveness through creating products or enhancing process effectiveness; however the economic benefits are not obvious, and R\&D expenses are consequently regarded as a high level of risk (Lin \& Wang, 2016). The question of how R\&D investment affects a firm's valuation is not novel, and neither has there been any robust evidence found. Different scholars have different insights about a firm's R\&D investment decisions. First, as Ang and Cheng (2011) explained, the signaling theory contends that companies have benefits to interact with the stock market to reduce asymmetric information among managers (insiders) and investors (outsiders). Because companies with good asymmetric information are expected to remain undervalued in the stock market, high-quality companies may be given options that their opponents do not understand and may try to communicate reports that market investors can distinguish from low-quality companies. The future outflows from stock investments are highly uncertain making R\&D expenditures extremely risky. Research and development expenditures are also more likely to suffer from information asymmetry among investors (outsiders) and managers (insiders) than other types of investments (Kim \& Park, 2020). According to Cohen, Diether, and Malloy (2013), investors demand a more extended anticipated profit to support the tremendous risk of research and development expenses, which are likely to result in firm mispricing.

Numerous pieces of evidence in the literature support that the active $R \& D$ firms outperformed inactive $R \& D$ firms in excess returns (Yu et al., 2020) and provided a predictable sign to the market about firms' future earnings (Kim \& Park, 2020). Grabowksi and Mueller (1978) and Warusawitharana (2015) investigated the effect of R\&D investments on company profitability and found that companies that invest highly in R\&D projects are more profitable. According to Franzen, Rodgers, and Simin (2007), higher research and development expenditure increases the probability of misidentifying solvent companies while adjusting for conservative R\&D accounting to maximize the number of clearly identified distressed and highly distressed value firms. Several research studies demonstrate that companies with significant research and development investment have higher excess returns within the US and non-US markets (Lu, 2020; Sinha et al., 2019). Innovative companies are generally accepted to achieve a competitive edge in innovation and $\mathrm{R} \& \mathrm{D}$ and thus achieve premium market value and higher profitability (Xu \& Zhang, 2004). Sougiannis (1994) suggested that the current book value is based on future surplus cash flow, which confirms that $R \& D$ investment is a determinant of the future surplus earnings of a firm. Their paper also implies that examining a firm's value, capitalization, and the difference between book equity and its market value can explain its marketing costs and research and development efficiency. Kim and Park (2020) explained that the book to market $(\mathrm{B} / \mathrm{M})$ ratio indicates a company's future growth potential. They examined both portions as regressors and found a positive correlation between research and development investment and firm future growth. From 1999 to 2011, Duqi, Mirti, and Torluccio (2011) studied an extensive data set comprising 13 European 
countries. Using the regression equation, they argued that companies with significant research and development investments have relatively higher excess returns and overall firm value. Gu (2016) studied competitive intensity, $\mathrm{R} \& \mathrm{D}$ investment and equity returns for US-listed firms between 1963 and 2013, and the findings showed that active $R \& D$ firms have a substantial market value compared with inactive R\&D firms. Additionally, other studies and statistical analyses of research and development investment in similar cases have observed an essential link between research and development investments, firm market value and equity returns in other developing countries such as Turkey (Başgoze \& Sayin, 2013), India (Majumdar, 2011; Sinha et al., 2019), Pakistan (Ghaffar \& Khan, 2014) and China (Lu, 2020). In addition, the majority of research studies on R\&D return premium primarily focus on high R\&D countries such as the US (Dongmei, 2011; Lin \& Wang, 2016; Yu et al., 2020), South Korea (Kim \& Park, 2020), Brazil (Da Silva, Klotzle, Pinto, \& Da Motta, 2018), China (Lu, 2020), Korea, Finland and Israel (Yury, Albert, \& Ilia, 2017). Surprisingly, none of the studies considered the Indian context. In this study, the average annual R\&D premium for the Indian equity market was around $20 \%$ in the decile portfolio (P1 - P10), which is significantly greater than the R\&D return premiums in other countries, as documented by Yu et al. (2020) in the US stock market and Kim and Park (2020) in the South Korean stock market. This research article is one of the few to examine the cost of traded research and development in India as a developing market. This study investigates the $\mathrm{R} \& \mathrm{D}$ return premium for the Indian equity market using the most prominent asset pricing models to describe portfolio monthly returns. The primary aim is to price the traded research and development factor, which is the difference in return premiums between active and inactive $\mathrm{R} \& \mathrm{D}$ firms.

This paper aims to measure the well-organized $R \& D$ premium in the Indian equity market by calculating the systematic R\&D factor. The paper develops and tests a traded R\&D factor closely related to Yu et al. (2020) and Chan et al. (2001) and also explores the three most prominent pricing models: the CAPM (Capital Asset Pricing Model), the Fama and French (1993) three-factor (FF3F) model, and the Fama and French (2015) five-factor $(\mathrm{FF} 5 \mathrm{~F})$ model. This study also examines R\&D factor augmented CAPM, FF3F and FF5F models to price traded $\mathrm{R} \& \mathrm{D}$ investment for the Indian equity market. Section two of this paper describes the data and methodology; section three comprises the results and analysis; section four concludes and provides recommendations for future research.

\section{METHODOLOGY}

This study aims to investigate the $R \& D$ return premium in the Indian equity market. This paper examines the existence of a recurring R\&D premium using the three most prominent asset pricing models - CAPM, FF3F and FF5F.

\subsection{Data}

The CMIE Prowess IQ financial database was used to collect data for variables such as returns, adjusted closing prices, R\&D expenditure, $\mathrm{P} / \mathrm{B}$ (price to book) ratio, total assets, sales, market capitalization, operating profit, and book equity. It included all R\&D invested firms listed at the BSE (Bombay Stock Exchange) from July 2009 to June 2021. To eliminate diversification problems and maintain an adequate number of firms when calculating factors, constructing different portfolios, and testing asset pricing models, we closely followed the methodology suggested by Fama and French (1993), Fama and French (2008) and Fama and French (2015). Firms with no R\&D expenditure, negative $\mathrm{P} / \mathrm{B}$ ratios, and missing adjusted closing prices during the year were excluded from the data set to avoid any survivorship bias (Kundlia \& Verma, 2021; Lin \& Wang, 2016). As a result, the final sample included an average of 524 firms per year during the sample period. The BSE 500 index monthly return was utilized as a market return for the construction of the market factor, and the rate of 91 days of T-bills was used as a risk-free return proxy. 


\subsection{REDD Ratio Measure}

According to Chan et al. (2001), the R\&D ratio was calculated as the previous year's research and development expenditure-to-market equity value to calculate the R\&D factor and sort the decile and 2 x 3 sorted portfolios. We scaled the $\mathrm{R} \& \mathrm{D}$ ratio with market equity because this produced more consistent returns in the decile portfolio than scaling with sales $(\mathrm{R} \& \mathrm{D} /$ sales) and total assets (R\&D/total asset), as proposed by Yu et al. (2020). Figure 1 presents the decile portfolio monthly returns while scaling $\mathrm{R} \& \mathrm{D}$ ratio by market equity, sales and total assets. $\mathrm{P} 1$ represents the predicted monthly returns for an active (high) R\&D firm's portfolio, while P1O depicts the expected monthly returns for an inactive (low) R\&D firm's portfolio. The results in the decile portfolio returns are consistent with high $\mathrm{R} \& \mathrm{D}$ firms versus low $\mathrm{R} \& \mathrm{D}$ stocks.

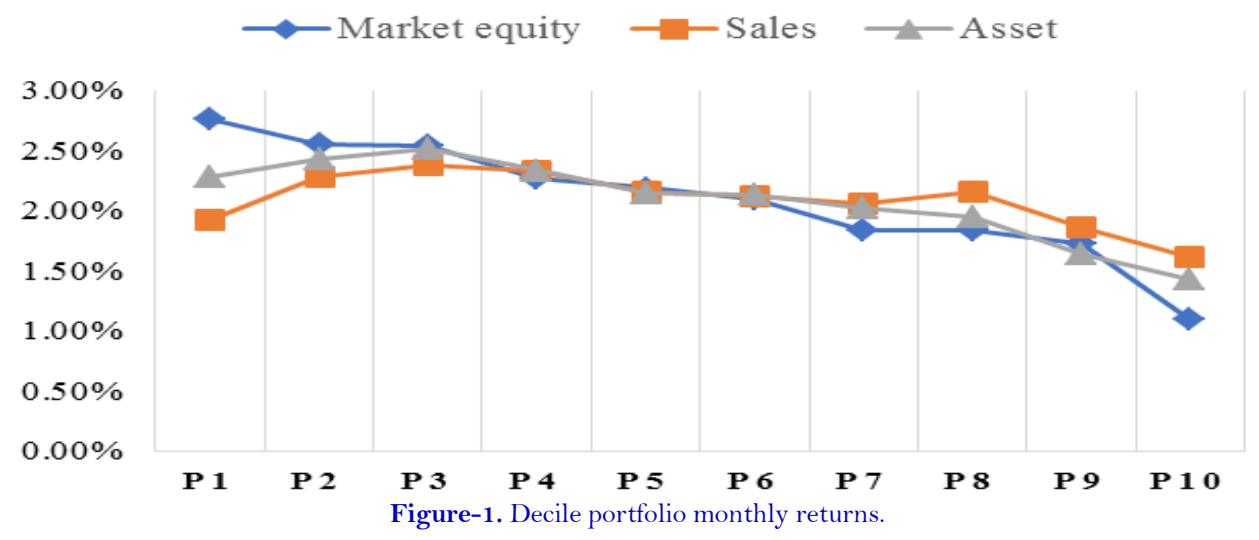

\subsection{Variables}

Five specific risk determinants were chosen ( $\mathrm{R} \& \mathrm{D}$ ratio, firm size, $\mathrm{P} / \mathrm{B}$ value, profitability and investment) to test asset pricing models. The traded $R \& D$ factor (AMI) is the difference between active and inactive R\&D stocks and was calculated using the methodology used by Chan et al. (2001). Any short-term movement and refusal effects from increased R\&D intensity were withdrawn. Furthermore, six (2x3) size/value, size/profitability, and size/investment-mimicking portfolios were created utilizing Fama and French (2015) SMB (size), LMH (value), RMW (profitability), and CMA (investment) factors. All factors were calculated using equally weighted monthly average returns. The market factor was calculated as the market portfolio return minus the risk-free rate of return using the Sharpe (1964) and Lintner (1965) procedures. In addition, univariate R\&D decile portfolios were formed for pricing methodical R\&D portfolios and evaluating asset pricing models. P1 to P10 indicate excess portfolio monthly returns on $\mathrm{R} \& \mathrm{D}$ deciles. These scales were formed as portfolio returns of high $\mathrm{R} \& \mathrm{D}$ (active) stocks (P1) to a portfolio of low R\&D (inactive) stocks (P10).

\subsection{Specification of Models}

In line with prior studies (Cremers, Nair, \& John, 2009; Kim \& Park, 2020; Lin \& Wang, 2016) this paper investigates the role of comprehensive $\mathrm{R} \& \mathrm{D}$ intensity in asset pricing models. First, the existing pricing models CAPM, FF3F and new FF5F were examined in Equations 1, 2, and 3. Then, the R\&D factor was added to the CAPM, FF3F and FF5F, and the new models were examined in Equations 4, 5, and 6, respectively.

$$
\begin{aligned}
& R_{\mathrm{it}-} R_{f \mathrm{t}}=\alpha_{\mathrm{i}}+\beta_{R m R f_{\mathrm{i}}} *^{R m R f_{\mathrm{t}}}+\varepsilon_{\mathrm{it}} \\
& R_{\mathrm{it}-} R_{f \mathrm{t}}=\alpha_{\mathrm{i}}+\beta_{R m R f_{\mathrm{i}}} *^{R m R f_{\mathrm{t}}}+\beta_{S M B_{i}} *^{S M B_{\mathrm{t}}}+\beta_{\mathrm{LMH} \mathrm{i}} *^{2 M H_{\mathrm{t}}}+\varepsilon_{\mathrm{it}}
\end{aligned}
$$




$$
R_{\mathrm{it}-} R_{f \mathrm{t}}=\alpha_{\mathrm{i}}+\beta_{R m R f_{i}} *^{R m R f_{\mathrm{t}}}+\beta_{S M b_{\mathrm{i}}} *^{S M B_{\mathrm{t}}}+\beta_{2 M H_{i}} *^{2 M H_{\mathrm{t}}}+\beta_{R M W_{i}} *^{R M W_{\mathrm{t}}}+\beta_{\mathrm{CMAi}} *^{C M A_{\mathrm{t}}}+\varepsilon_{\mathrm{it}}
$$

$$
\begin{aligned}
& R_{\mathrm{it}-} R_{f t}=\alpha_{\mathrm{i}}+\beta_{R m R f_{\mathrm{i}}}{ }^{R m R f_{\mathrm{t}}}+\beta_{I M A_{\mathrm{i}}} *^{l M A_{\mathrm{t}}}+\varepsilon_{\mathrm{it}} \\
& R_{\mathrm{it}-} R_{f \mathrm{t}}=\alpha_{\mathrm{i}}+\beta_{R m R f_{\mathrm{i}}} *^{R m R f_{\mathrm{t}}}+\beta_{S M B_{i}} *^{S M B_{\mathrm{t}}}+\beta_{L M H_{i}} *^{L M H_{\mathrm{t}}}+\beta_{I M A_{i}} *^{l M A_{\mathrm{t}}}+\varepsilon_{\mathrm{it}} \\
& R_{\mathrm{it}-} R_{f \mathrm{t}}=\alpha_{\mathrm{i}}+\beta_{R m R f_{\mathrm{i}}}{ }^{R m R f_{\mathrm{t}}} \\
& +\beta_{S M B_{i}} *^{S M B_{\mathrm{t}}}+\beta_{\mathrm{LMH}_{\mathrm{i}}} *^{2 M H_{\mathrm{t}}}+\beta_{R M W_{i}} *^{R M W_{\mathrm{t}}}+\beta_{\mathrm{CMA}} *^{C M A_{\mathrm{t}}}+\beta_{I M A_{\mathrm{i}}} *^{I M A_{\mathrm{t}}}+\varepsilon_{\mathrm{it}}
\end{aligned}
$$

Based on Fama and French (1993) the excess returns for the decile portfolios were constructed following the multiple time-series OLS regression used by Black, Jensen, and Scholes (1972). Utilizing the GRS test (Gibbons, Ross, \& Shanken, 1989), the effectiveness of purposed pricing model intercepts were examined to test whether model intercepts are jointly zero. Furthermore, the time-series findings were validated using the Fama and MacBeth (1973) two-step cross-sectional regression analysis.

\section{RESULTS AND ANALYSIS}

Table 1 shows the descriptive statistics for the factors' monthly returns. In the Indian equity market, the average monthly $\mathrm{R} \& \mathrm{D}$ premium is $0.77 \%$, which is significantly greater than the other factor premiums such as market $(0.55 \%)$, size $(0.73 \%)$, value $(0.058 \%)$, profitability $(0.32 \%)$, and investment $(-0.037 \%)$. When we compared the return diagonal as an $\mathrm{R} \& \mathrm{D}$ factor time-series monthly return, we found it to be at $0.77 \%$ in the Indian stock market, which is higher than in similar studies by Yu et al. (2020) on the US stock market in high- and low-tech industries and by Kim and Park (2020) on the South Korean stock market. The time-series standard deviation of the $\mathrm{R} \& \mathrm{D}$ factor was $1.88 \%$, which was significantly lower than the standard deviations of other factors such as market (5.24\%), size (3.51\%), value (3.17\%), profitability (1.97\%), and investment $(1.97 \%)$.

Table-1. Results from descriptive statistics for factor risk.

\begin{tabular}{c|c|c|c|c|c|c}
\hline & Rm-Rf & SMB & LMH & RMW & CMA & AMI \\
\hline Mean & 0.00546 & $0.0073^{*} *$ & 0.00058 & $0.0032^{*}$ & -0.00037 & $0.0077^{*} * *$ \\
\hline$t$-stat & 1.25 & 2.49 & 0.22 & 1.75 & -0.22 & 4.91 \\
\hline Median & 0.00561 & 0.00555 & -0.00179 & 0.00422 & 0.00047 & 0.00597 \\
\hline Minimum & -0.24483 & -0.06933 & -0.07465 & -0.06693 & -0.05426 & -0.03743 \\
\hline Maximum & 0.14323 & 0.13793 & 0.11988 & 0.06065 & 0.06293 & 0.06790 \\
\hline Standard deviation & 0.05242 & 0.03512 & 0.03167 & 0.01969 & 0.01971 & 0.01884 \\
\hline Skewness & -0.61387 & 0.80506 & 0.60193 & -0.43503 & 0.08174 & 0.60595 \\
\hline Kurtosis & 5.74793 & 3.89107 & 3.87170 & 4.41916 & 4.05029 & 3.79099 \\
\hline Jarque-Bera & 54.35086 & 20.31883 & 13.25654 & 16.62620 & 6.77904 & 12.59099 \\
\hline Probability & 0.00000 & 0.00004 & 0.00132 & 0.00024 & 0.03373 & 0.00185 \\
\hline Observations & 144 & 144 & 144 & 144 & 144 & 144 \\
\hline
\end{tabular}

Notes: $R m-R f$ denotes the market risk factor as a market risk premium, the excess returns on the market portfolio return. $S M B$ is the size factor in a size premium, distinguishing between the returns of small-cap and large-cap stocks. $L M H$ is the value factor in the context of a value premium, which is the difference between the returns of value and growth stocks. $R M W$ is the profitability factor in the portion of a profit premium that distinguishes between robust and weak firm returns. CMA is an investment factor in the form of an investment premium that represents the difference between the returns of conservative and aggressive investment firms. Similarly, $A M I$ is the R\&D factor in the pattern of an $R \& D$ premium, which is the active $R \& D$ versus inactive $R \& D$ firms' returns. ${ }^{* * *} \mathrm{p}<0.01$, , $^{*} \mathrm{p}<0.05$ and $* \mathrm{p}<0.1$.

Table 2 presents detailed statistics for portfolio excess returns of R\&D decile sorted portfolios. P1 denotes the abnormal returns for the high (active) R\&D-intensive firms, while P10 denotes the abnormal returns for the low (inactive) R\&D-intensive firms. The time-series monthly excess return on portfolio P1 (the high R\&D stocks) is $2.20 \%$, while the monthly excess return on $\mathrm{P} 10$ (the low R\&D stocks) is $0.50 \%$. Excess monthly returns towards the 
decile portfolios increased monotonically in tandem with firms' R\&D investment. Results concluded that the annualized R\&D premium in the decile portfolios (P1 - P10) is approximately $20.40 \%$, which is considerably high.

Table-2. Results from descriptive statistics for univariate sorted decile portfolio monthly excess returns.

\begin{tabular}{c|c|c|c|c|c|c|c|c|c|c}
\hline & P1 & P2 & P3 & P4 & P5 & P6 & P7 & P8 & P9 & P10 \\
\hline Mean & 0.022 & 0.020 & 0.020 & 0.017 & 0.016 & 0.016 & 0.013 & 0.013 & 0.012 & 0.005 \\
\hline$t$-stat & 2.997 & 2.844 & 3.097 & 2.544 & 2.420 & 2.484 & 2.050 & 2.280 & 2.051 & 1.035 \\
\hline Median & 0.016 & 0.011 & 0.025 & 0.017 & 0.016 & 0.016 & 0.011 & 0.012 & 0.012 & 0.011 \\
\hline Min. & -0.256 & -0.293 & -0.281 & -0.306 & -0.312 & -0.269 & -0.299 & -0.293 & -0.259 & -0.265 \\
\hline Max. & 0.261 & 0.283 & 0.223 & 0.233 & 0.269 & 0.207 & 0.238 & 0.187 & 0.216 & 0.158 \\
\hline SD & 0.089 & 0.085 & 0.077 & 0.082 & 0.082 & 0.075 & 0.076 & 0.068 & 0.069 & 0.064 \\
\hline Skew. & -0.284 & -0.027 & -0.378 & -0.191 & -0.283 & -0.194 & -0.321 & -0.502 & -0.283 & -0.472 \\
\hline Kurt. & 3.596 & 4.046 & 3.858 & 4.182 & 4.216 & 3.811 & 4.327 & 4.981 & 3.954 & 4.574 \\
\hline J-B & 9.250 & 6.587 & 7.862 & 9.278 & 10.760 & 4.848 & 13.052 & 29.810 & 7.269 & 20.216 \\
\hline Prob. & 0.004 & 0.037 & 0.019 & 0.010 & 0.005 & 0.088 & 0.001 & 0.000 & 0.026 & 0.000 \\
\hline Obs. & 144 & 144 & 144 & 144 & 144 & 144 & 144 & 144 & 144 & 144 \\
\hline Not
\end{tabular}

Notes: The table contains the statistical results of univariate sorted decile portfolios. P1 denotes the statistical results for the excess monthly returns on the portfolio of high (active) R\&D stocks, while P10 defines the statistical results for the portfolio of low (inactive) R\&D stocks.

\subsection{Evidence from Time-Series Regressions}

The CAPM and the R\&D factor added CAPM results are shown in Table 3. First, Panel A was examined using Equation 1 to test whether the CAPM could explain excess periodical returns toward decile sorted portfolios. The results show that the risk-mimicking market factor was significant at the $1 \%$ level. All portfolio intercepts were statistically significant except for the low R\&D portfolio (P10). The results also show that CAPM cannot fully describe the R\&D decile portfolios' excess returns because the intercept values were statistically significant. The intercepts show an increasing trend in the R\&D portfolios as firms' $R \& D$ investment increases. We also noticed that the models' validity was positively affected from portfolio P1 to portfolio P10, denoting that the asset pricing model is ineffective at describing the excess monthly returns towards the decile portfolios of high R\&D firms. Panel $B$ depicts the $\mathrm{R} \& \mathrm{D}$ factor augmented CAPM used to test the price of $\mathrm{R} \& \mathrm{D}$ decile portfolios. After the R\&D factor was added to the CAPM, the model improved because all intercepts became insignificant. The market factor and the $\mathrm{R} \& \mathrm{D}$ risk factor were also significant in describing monthly excess returns for all decile R\&D portfolios. We also found that when the R\&D factor augmented CAPM operated, the R-squared values in the models for each portfolio consistently increased. In addition, we also used the GRS test (Gibbons et al., 1989) to examine whether all intercepts' models are significant and jointly equivalent to 0 . The p-value for the GRS statistic through CAPM was $0.02 \%$, which is less than 5\%, indicating that the CAPM's intercepts (alphas) are not equivalent to 0 . The p-value of the GRS statistic for the CAPM with the incorporated R\&D factor was $10.06 \%$, indicating that intercept aspects for portfolios are significant and jointly equivalent to 0 . As a result, it was concluded that in the Indian stock market, the CAPM cannot clearly explain excess returns on equity, and the R\&D factor integrated CAPM worked better.

The Fama and French (1993) three-factor (FF3F) model for R\&D premium was also evaluated, the findings are exhibited in Panel C. The FF3F model was used to see whether it could describe the monthly excess returns on the R\&D decile portfolios. It showed that the correlation coefficients of market and size risk-mimicking factors were statistically significant to all R\&D decile portfolios. In contrast, the value factor cannot significantly explain several portfolios. The values of intercepts of the top $33.33 \%$ high R\&D firm portfolios became statistically significant, indicating that the FF3F model cannot fully explain the excess returns for high R\&D stocks. While the $\mathrm{R} \& \mathrm{D}$ factor was placed in the FF3F model in Panel D, it was observed that the intercept terms decreased and became completely insignificant for all models. The R\&D factor significantly explains excess returns for five portfolios with high R\&D portfolio, namely P1 - P5. We also found that when the R\&D factor was integrated into the FF3F model, the R-squared value of all models improved and its value was considerably higher than the pure FF3F model. We used the GRS test to examine whether the intercepts of all models are significant and jointly 
equivalent to 0 . The p-value of the GRS statistic for the FF3F model was $0.18 \%$, which is less than $5 \%$, indicating that the FF3F model's intercepts are not equivalent to o. The p-value in the GRS test for the FF3F model with the added $\mathrm{R} \& \mathrm{D}$ factor was $14.10 \%$, indicating that the intercepts on portfolios are jointly equivalent to 0 . As a result, in the Indian stock market, it was concluded that the FF3F model could not fully explain excess monthly returns toward these high R\&D firms and that the FF3F model with the integrated R\&D factor performs better.

In addition, we also tested whether the new five-factor asset pricing model (FF5F) (Fama \& French, 2015) can explain the excess monthly returns of R\&D sorted decile portfolios (see Table 4). The coefficients of market, size, and value risk factors were statistically significant for all decile portfolios. In comparison, only a few of the profitability and investment risk factors were statistically significant. When the intercepts of the models were examined, it was found that $40 \%$ of $\mathrm{R} \& \mathrm{D}$ decile portfolios were statistically significant. This also implies that the FF5F model could not fully explain the excess returns for the R\&D sorted decile portfolios. However, when the $\mathrm{R} \& \mathrm{D}$ factor was incorporated into the $\mathrm{FF} 5 \mathrm{~F}$ model, the intercept terms decreased and all intercepts became completely insignificant for all models, while the R-squared values also increased slightly. Regarding the GRS test results, the p-value for the $\mathrm{FF} 5 \mathrm{~F}$ model was $0.46 \%$, which is less than $5 \%$, indicating that the $\mathrm{FF} 5 \mathrm{~F}$ model's intercepts are not jointly equivalent to 0 . The p-value of the GRS statistic via the R\&D factor blended FF5F model was $16.93 \%$, indicating that the intercepts on portfolios were jointly equivalent to 0 . In conclusion, the FF $5 \mathrm{~F}$ model cannot fully explain the excess monthly returns for these high R\&D firms, and the FF5F model performs better with the integrated $\mathrm{R} \& \mathrm{D}$ factor. Based on the time-series evidence, it is possible to conclude that the $\mathrm{R} \& \mathrm{D}$ risk factor for the Indian market is indeed predictable, and investors can consider it when developing pricing models. According to the findings of this study, the R\&D factor added CAPM, FF3F and new FF5F models effectively outperformed the traditional CAPM, FF3F and FF5F models.

\subsection{Evidence from the Cross-Sectional Model}

To explore the results of the selected three most important asset pricing models - CAPM, FF3F and FF5F - a traditional Fama and Macbeth two-step procedure was used (Fama \& MacBeth, 1973). By strengthening the R\&D factor in the CAPM, FF3F and FF5F models, the significance and existence of the R\&D premium were also investigated. Below are the models that have been put to the test:

$$
\begin{aligned}
& r_{\mathrm{it}}=\gamma^{0}+\gamma^{2 *} \beta_{R m R f, i}+\varepsilon_{\mathrm{it}} \\
& r_{\mathrm{it}}=\gamma^{0}+\gamma^{2} \cdot \beta_{R m R f, i}+Y^{6 *} \beta_{M M A, i}+\varepsilon_{\mathrm{it}} \\
& r_{\mathrm{it}}=\gamma^{0}+\gamma^{2} \cdot \beta_{R M R f, i}+Y^{2} \cdot \beta_{S M B, i}+\gamma^{2 *} \beta_{L M H, i}+\varepsilon_{\mathrm{it}} \\
& r_{\mathrm{it}}=\gamma^{0}+\gamma^{2} \cdot \beta_{R M R f_{i} i}+\gamma^{2 *} \beta_{S M B, i}+\gamma^{2 *} \beta_{L M H, i}+\gamma^{6} \cdot \beta_{M M A, i}+\varepsilon_{\mathrm{it}}
\end{aligned}
$$

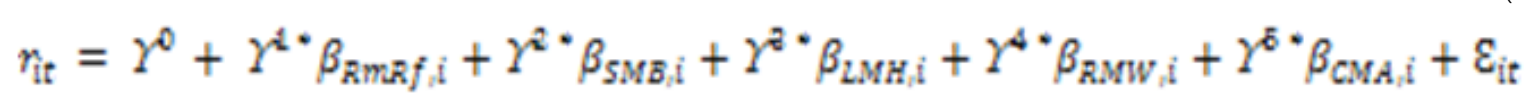

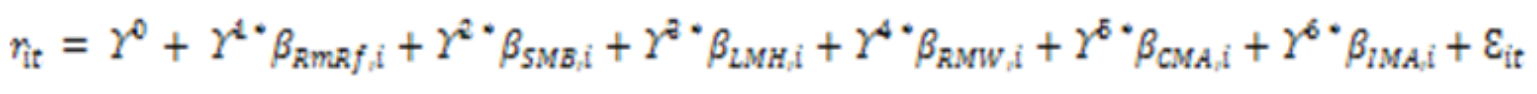

Equation 7, 9, and 11 cross-sectionally test the findings for the CAPM, FF3F and new FF5F models individually. Equation 8, 10 and 12 provide cross-sectional confirmation for R\&D risk factors for the augmented CAPM, FF3F and new FF5F models, respectively. Table 5 represents the results from the two-pass procedure of the cross-sectional regression (Fama \& MacBeth, 1973). 
Asian Economic and Financial Review, 2021, 11(10): 816-828

Table-3. CAPM and FF3F models tested for R\&D premium.

\begin{tabular}{|c|c|c|c|c|c|c|c|c|c|c|}
\hline \multicolumn{11}{|c|}{ Panel A: CAPM } \\
\hline & P1 & P2 & P3 & $\mathbf{P 4}$ & P5 & P6 & P7 & P8 & P9 & P10 \\
\hline$\alpha$ & $0.015^{* * * *}$ & $0.013^{*} * * *$ & $0.014 * * *$ & $0.011 * *$ & $0.009^{*} *$ & $0.009^{*} *$ & $0.006^{*}$ & $0.007^{*} *$ & $0.005^{*} *$ & 0.000 \\
\hline$\beta_{\mathrm{Rm}-\mathrm{Rf}}$ & 1.29 *** & 1.27 ***** & $1.178^{*} * * *$ & $1.24 * * * *$ & $1.28 * * * *$ & $1.16^{* * * *}$ & $1.24 * * * *$ & $1.14^{* * * * *}$ & $1.17 * * * *$ & $1.07^{* * * *}$ \\
\hline $\mathrm{R}^{2}$ & 0.58 & 0.62 & 0.64 & 0.63 & 0.68 & 0.66 & 0.73 & 0.76 & 0.78 & 0.77 \\
\hline \multicolumn{4}{|c|}{ GRS_F-test } & \multicolumn{2}{|c|}{3.678313} & \multicolumn{3}{|c|}{ GRS p-value } & \multicolumn{2}{|c|}{0.000231} \\
\hline \multicolumn{11}{|c|}{ Panel B: R\&D factor in the augmented CAPM } \\
\hline$\alpha$ & 0.002 & 0.000 & 0.004 & 0.002 & 0.001 & 0.003 & 0.002 & 0.003 & 0.002 & -0.003 \\
\hline$\beta_{\mathrm{Rm}-\mathrm{Rf}}$ & 1.17 **** & $1.16^{* * * * *}$ & $1.09^{* * * *}$ & $1.16^{* * * *}$ & $1.21^{*} * * *$ & $1.11^{*} * * *$ & $1.19^{* * * *}$ & $1.10^{* * * *}$ & $1.14^{*} * * *$ & $1.54 * * * *$ \\
\hline$\beta_{\mathrm{AMI}}$ & $1.80^{* * * *}$ & $1.79^{*} * * *$ & $1.33 * * *$ & $1.23^{*} * *$ & $1.14^{* * * * *}$ & $0.81 * * *$ & 0.61 ***** & $0.52^{* * * *}$ & $0.41 * * * *$ & $0.31 * *$ \\
\hline $\mathrm{R}^{2}$ & 0.72 & 0.77 & 0.74 & 0.71 & 0.75 & 0.70 & 0.76 & 0.78 & 0.79 & 0.78 \\
\hline \multicolumn{4}{|c|}{ GRS_F-test } & \multicolumn{2}{|c|}{1.645262} & \multicolumn{3}{|c|}{ GRS p-value } & \multicolumn{2}{|c|}{0.100580} \\
\hline \multicolumn{11}{|c|}{ Panel C: FF3F model } \\
\hline$\alpha$ & $0.007 * * *$ & 0.006 *** & $0.007 * * *$ & 0.003 & 0.003 & 0.003 & 0.001 & $0.004 *$ & 0.003 & -0.003 \\
\hline$\beta_{\mathrm{Rm}-\mathrm{Rf}}$ & $1.02 * * *$ & 1.07 ***** & $1.02 * * *$ & $1.06 * * *$ & $1.10^{*} * * *$ & $0.98 * * *$ & 1.07 **** & $0.99^{* * * *}$ & $1.03 * * *$ & $0.94 * * *$ \\
\hline$\beta_{\mathrm{SMB}}$ & $1.24 * * * *$ & $1.12^{* * * * *}$ & $1.01 * * * *$ & 1.09 **** & 0.99**** & 0.89**** & $0.76^{*} * * * *$ & 0.49**** & $0.48^{*} * * *$ & $0.39 * * *$ \\
\hline$\beta_{\mathrm{LMH}}$ & $0.40^{* * * *}$ & $0.24 * *$ & 0.107 & 0.144 & $0.22^{* * *}$ & $0.24 * *$ & 0.26 **** & $0.29^{* * * *}$ & $0.29 * * *$ & $0.29 * * *$ \\
\hline $\mathrm{R}^{2}$ & 0.88 & 0.87 & 0.86 & 0.87 & 0.90 & 0.88 & 0.90 & 0.87 & 0.89 & 0.86 \\
\hline \multicolumn{4}{|c|}{ GRS_F-test } & \multicolumn{2}{|c|}{3.027326} & \multicolumn{3}{|c|}{ GRS p-value } & \multicolumn{2}{|c|}{0.001775} \\
\hline \multicolumn{11}{|c|}{ Panel D: R\&D factor in the augmented_FF3F model } \\
\hline$\alpha$ & 0.002 & 0.000 & 0.003 & 0.001 & 0.001 & 0.003 & 0.001 & 0.003 & 0.003 & -0.002 \\
\hline$\beta_{\mathrm{Rm}-\mathrm{Rf}}$ & $0.98^{* * * *}$ & $1.02^{* * * * *}$ & $0.99^{* * * *}$ & $1.04 * * *$ & $1.08^{* * * *}$ & 0.97 **** & 1.07 **** & $0.99^{* * * *}$ & $1.03^{* * * *}$ & 0.94**** \\
\hline$\beta_{\mathrm{SMB}}$ & $1.03 * * *$ & $0.88^{* * * *}$ & $0.86^{* * * *}$ & $0.98 * * *$ & $0.89^{* * * *}$ & $0.87 * * *$ & 0.75 **** & $0.46^{* * * *}$ & $0.48 * * *$ & $0.40^{* * * *}$ \\
\hline$\beta_{\mathrm{LMH}}$ & $0.43^{* * * *}$ & 0.27 ***** & 0.127 & 0.158 & $0.24 * * * *$ & $0.24 * *$ & $0.26^{* * * *}$ & $0.30^{* * * *}$ & $0.28^{*} * *$ & $0.29^{* * * *}$ \\
\hline$\beta_{\mathrm{AMI}}$ & 0.96*** & 1.09 **** & $0.69^{* * * *}$ & 0.49*** & $0.44^{* * * *}$ & 0.122 & 0.010 & 0.113 & -0.003 & -0.051 \\
\hline $\mathrm{R}^{2}$ & 0.92 & 0.91 & 0.88 & 0.88 & 0.91 & 0.88 & 0.90 & 0.87 & 0.89 & 0.86 \\
\hline GRS_F-test & & & & \multicolumn{2}{|c|}{1.514613} & & GRS p-valt & & \multicolumn{2}{|c|}{0.141047} \\
\hline
\end{tabular}


Table-4. FF5F model tested for R\&D premium.

\begin{tabular}{|c|c|c|c|c|c|c|c|c|c|c|}
\hline \multicolumn{11}{|c|}{ Panel A: FF5F model } \\
\hline & P1 & P2 & P3 & P4 & P5 & P6 & P7 & P8 & P9 & P10 \\
\hline$\alpha$ & $0.007 * * *$ & $0.005^{*}$ & $0.006 * *$ & 0.003 & 0.003 & 0.003 & 0.001 & $0.004 *$ & 0.002 & -0.003 \\
\hline$\beta_{\mathrm{Rm}-\mathrm{Rf}}$ & $1.01 * * *$ & $1.06^{* * * *}$ & $1.01 * * * *$ & $1.04 * * * *$ & $1.08^{* * * *}$ & $0.96^{* * * *}$ & 1.07 **** & $0.97^{* * * *}$ & $1.02^{* * * *}$ & $0.93^{* * * *}$ \\
\hline$\beta_{\mathrm{SMB}}$ & $1.24 * * *$ & $1.20^{* * * *}$ & $0.98^{* * * *}$ & $1.08^{* * *}$ & $0.98^{* * * *}$ & $0.89 * * *$ & 0.75 **** & $0.49^{* * * *}$ & $0.48^{* * * *}$ & $0.39^{* * * * *}$ \\
\hline$\beta_{\mathrm{LMH}}$ & $0.55^{* * * *}$ & $0.38^{* * *}$ & $0.34 * *$ & $0.44 * * * *$ & $0.46^{* * * * *}$ & $0.47 * * * *$ & 0.35 ***** & $0.49^{* * * *}$ & $0.36^{* * * * *}$ & $0.41^{*} * * *$ \\
\hline$\beta_{\mathrm{RMW}}$ & 0.038 & 0.261 & $0.35^{*}$ & 0.279 & 0.199 & 0.226 & 0.105 & 0.096 & 0.056 & 0.064 \\
\hline$\beta_{\mathrm{CMA}}$ & 0.289 & 0.036 & 0.153 & $0.37^{*}$ & $0.32^{*}$ & 0.280 & 0.098 & 0.328 & 0.099 & 0.201 \\
\hline $\mathrm{R}^{2}$ & 0.89 & 0.87 & 0.87 & 0.88 & 0.90 & 0.88 & 0.90 & 0.88 & 0.89 & 0.87 \\
\hline \multicolumn{4}{|c|}{ GRS_F-test } & \multicolumn{2}{|c|}{2.721153} & \multicolumn{3}{|c|}{ GRS p-value } & \multicolumn{2}{|c|}{0.004574} \\
\hline
\end{tabular}

GRS_F-test

Panel B: R\&D factor in the augmented _FF5F model

\begin{tabular}{|c|c|c|c|c|c|c|c|c|c|c|}
\hline$\alpha$ & 0.002 & -0.001 & 0.002 & 0.000 & 0.000 & 0.002 & 0.002 & 0.003 & 0.002 & -0.002 \\
\hline$\beta_{\mathrm{Rm}-\mathrm{Rf}}$ & $0.96^{* * * *}$ & $1.02 * * *$ & $0.98 * * *$ & $1.02 * * *$ & $1.06 * * *$ & $0.96 * * *$ & $0.05 * * *$ & $0.97 * * * *$ & $1.02^{* * * *}$ & 0.93*** \\
\hline$\beta_{\mathrm{SMB}}$ & $1.04 * * * *$ & $0.87 * * *$ & $0.85 * * * *$ & $0.99 * * *$ & $0.90 * * *$ & $0.87 * * * *$ & $0.08^{* * * *}$ & $0.48^{* * * *}$ & $0.48^{* * * *}$ & 0.41 **** \\
\hline$\beta_{\mathrm{LMH}}$ & $0.52 * * * *$ & 0.34 **** & 0.31 *** & 0.42 **** & 0.45 **** & 0.47 **** & $0.12 * * *$ & $0.49^{* * * * *}$ & $0.36^{* * * *}$ & $0.42^{* * * * *}$ \\
\hline$\beta_{\mathrm{RMW}}$ & -0.079 & 0.128 & 0.273 & 0.224 & 0.149 & 0.216 & 0.159 & 0.086 & 0.058 & 0.072 \\
\hline$\beta_{\mathrm{CMA}}$ & 0.263 & 0.007 & 0.135 & $0.36^{*}$ & $0.31 *$ & 0.278 & 0.167 & $0.33^{*}$ & 0.099 & 0.203 \\
\hline$\beta_{\mathrm{AMI}}$ & 95 **** & 1.08 **** & 0.66 **** & 0.45 **** & 0.41 * **** & 0.085 & 0.122 & 0.086 & -0.014 & -0.069 \\
\hline $\mathrm{R}^{2}$ & 0.93 & 0.92 & 0.89 & 0.89 & 0.91 & 0.88 & 0.90 & 0.88 & 0.89 & 0.87 \\
\hline GRS_F-test & & & & \multicolumn{2}{|c|}{1.441786} & \multicolumn{3}{|c|}{ GRS p-value } & \multicolumn{2}{|c|}{0.169284} \\
\hline
\end{tabular}

Notes: Tables $3 \& 4$ present the CAPM, FF3F, and FF 5 F models for R\&D premium. Excess monthly returns on R\&D decile portfolios were regressed via risk-mimicking factor Rm-R

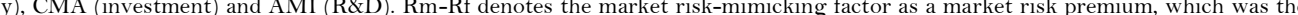
excess return on the market index portfolio. SMB was the size factor as a size premium, distinguishing between small-cap and large-cap firms. LMH is the value risk factor in the context of a value premium, which is the difference in return between value and growth stocks. RMW is the profitability factor in the portion of a profit premium that distinguishes between robust and weak firm returns. CMA is an investment factor in the form of an investment premium that represents the difference between the returns of conservative and aggressive investment firms. inflation factors) were tested for all risk factors for multicolinearity. Multicollinearity was observed to be non-existent. **** $\mathrm{p}<0.01$ ** $\mathrm{p}<0.05$, $\mathrm{p}<0.1$. 
The results indicate that the CAPM performs well because the market risk-mimicking factor was significantly associated; however, the R-squared value was relatively low at $21 \%$, which was more diminutive than the R-squared values of the other five models. The FF3F and FF5F models performed better than the CAPM, but only the size risk-mimicking factor was significant in describing cross-sectional monthly excess returns in the R\&D sorted portfolios. The R-squared values of the FF3F and FF5F models are considerable, and the model explains $49 \%$ and $66 \%$ of the excess returns on tested portfolios, respectively. While the R\&D risk factor was expanded within the $\mathrm{CAPM}, \mathrm{FF} 3 \mathrm{~F}$ and $\mathrm{FF} 5 \mathrm{~F}$ models, it was revealed that $\gamma 6$ is significant, indicating that the R\&D factor is predictable. When the R\&D factor was extended in the CAPM, FF3F and FF5F models, they shown improvement and explained the excess returns of $36 \%, 60 \%$ and $76 \%$, respectively, intimating that the R-squared values were consistently higher than the pure CAPM, FF3F and FF5F models.

The cross-sectional evidence showed that strengthening the R\&D risk-mimicking factor into the CAPM, FF3F and FF5F models helped to improve the models because the R\&D factor is significant when incorporated. The R\&D risk factor extended the CAPM, FF3F and FF5F models, which outperformed the traditional CAPM, FF3F and $\mathrm{FF} 5 \mathrm{~F}$ models in this section. When we ran the cross-sectional regression models, the size and R\&D risk factors performed better in explaining excess returns because both were continuously significant. This result also remains compatible with the conclusions of time-series evidence.

Table-5. Cross-sectional (Fama.. \& MacBeth, 1973) two-step procedure asset pricing tests.

\begin{tabular}{|c|c|c|c|c|c|c|c|c|c|}
\hline Model & $\gamma 0$ & $\gamma_{1}$ & $\gamma 2$ & $\gamma 3$ & $\gamma_{4}$ & $\gamma 5$ & $\gamma 6$ & $\mathbf{R}^{2}$ & F-stat. [p-value] \\
\hline CAPM & $-0.047 * * *$ & $0.052^{* * *}$ & & & & & & 0.21 & $16.22[0.000]$ \\
\hline $\begin{array}{l}\text { R\&D factor } \\
\text { augmented } \\
\text { CAPM }\end{array}$ & -0.004 & 0.010 & & & & & $0.008^{* * *} *$ & 0.36 & $9.62[0.000]$ \\
\hline FF3F & 0.000 & 0.002 & $0.015^{* * *}$ & 0.002 & & & & 0.49 & $6.37[0.001]$ \\
\hline $\begin{array}{c}\text { R\&D factor } \\
\text { augmented } \\
\text { FF3F }\end{array}$ & 0.001 & 0.005 & $0.010 * *$ & 0.000 & & & $0.007 * * *$ & 0.60 & $5.01[0.000]$ \\
\hline FF5F & -0.016 & 0.011 & $0.011^{* *}$ & 0.031 & 0.012 & -0.015 & & 0.66 & $3.99[0.002]$ \\
\hline $\begin{array}{c}\text { R\&D factor } \\
\text { augmented } \\
\text { FF 5F }\end{array}$ & -0.01 & 0.01 & $0.008 *$ & 0.017 & 0.008 & -0.006 & $0.007^{*} * *$ & 0.76 & $3.41[0.004]$ \\
\hline
\end{tabular}

Notes: Table 5 presents the CAPM, FF3F and FF5F models for R\&D premium. Excess monthly returns on R\&D decile portfolios were regressed via risk-mimicking factor Rm-Rf (market), SMB (firm size), LMH (value), RMW (profitability), CMA (investment) and AMI (R\&D). Rm-Rf denotes the market risk-mimicking factor as a market risk premium, which was the excess return on the market index portfolio. SMB was the size factor as a size premium, distinguishing between small-cap and large-cap firms. LMH is the value risk factor in the context of a value premium, which is the difference in return between value and growth stocks. RMW is the profitability factor in the portion of a profit premium that distinguishes between robust and weak firm returns. CMA is an investment factor in the form of an investment premium that represents the difference between the returns of conservative and aggressive investment firms. Similarly, AMI is the research and development factor as an $\mathrm{R} \& \mathrm{D}$ return premium, which is the difference between active $\mathrm{R} \& \mathrm{D}$ and inactive $\mathrm{R} \& \mathrm{D}$ firms. ${ }^{* * * *} \mathrm{p}<0.01$, $* * \mathrm{p}<0.05$, ${ }^{*} \mathrm{p}<0.1$.

\section{CONCLUSION AND FUTURE RESEARCH}

This paper's main goal was to examine the R\&D risk-mimicking factor in classical pricing models and investigate systematic R\&D premium for the Indian equity market. This study examined R\&D premium using three of the most prominent asset pricing models: the CAPM, FF3F model (Fama \& French, 1993) and FF5F model (Fama \& French, 2015). The results show that a significant and positive R\&D premium exists in the Indian equity market. Results also show that the annualized average R\&D premium is significantly higher than the existing value, market, profitability, size and investment premiums during the sample period. The annualized average R\&D premium for the Indian equity market was around 20\%, which is significantly greater than the R\&D premiums in other countries, as documented by Yu et al. (2020) in the US stock market in high-tech and low-tech industries and by Kim and Park (2020) in the South Korean stock market. It was found that the average monthly R\&D factor return was $0.77 \%$, which is significantly higher than the other risk factors such as market (0.55\%), size (0.73\%), value $(0.058 \%)$, profitability $(0.32 \%)$, and investment (-0.037\%). While the CAPM, FF3F and FF5F models were evaluated, it was observed that they were unable to describe the portfolios' monthly excess returns adequately and 
the joint implication from intercept aspects indicates that these models jointly provide non-zero significant intercepts. However, the R\&D factor extended CAPM, FF3F and FF5F models outperformed the traditional CAPM, FF3F and FF5F models. When R\&D factor augmented models were evaluated for intercept aspects, each model jointly provided zero intercepts. It was concluded that investors assess R\&D firms; the R\&D factor was predictable, and investors should include the $\mathrm{R} \& \mathrm{D}$ as a risk-mimicking factor while implementing pricing models in the Indian equity market. The paper's conclusions also indicate that the R\&D factor added CAPM, FF3F and FF5F models are good because they produced similar results while testing time-series and cross-sectional regression analyses.

The paper's findings contribute to the asset pricing literature and aid in developing robust asset pricing models for developing countries such as India. Investors can make profitable trading and investment decisions if they know the positive and essential $\mathrm{R} \& \mathrm{D}$ premium for the Indian equity market. Portfolio managers and investment professionals can construct portfolios by focusing on high R\&D firms while minimizing risk.

The R\&D factor developed and tested in this paper defines the new risk-mimicking factor linked with $\mathrm{R} \& \mathrm{D}$ investment. This $\mathrm{R} \& \mathrm{D}$ factor can be evaluated for firms, industries, or countries that invest significant capital in $\mathrm{R} \& \mathrm{D}$ activities. To identify the variations in $\mathrm{R} \& \mathrm{D}$ investment during times of uncertainty and crisis, a time-varying attribute of the R\&D factor can also be predicted.

Funding: This study received no specific financial support.

Competing Interests: The authors declare that they have no competing interests.

Acknowledgement: Both authors contributed equally to the conception and design of the study.

\section{REFERENCES}

Ang, J., \& Cheng, Y. (2011). The endogeneity of information asymmetry and corporate financing decisions. Journal of Financial Research, 34(3), 411-440. Available at: https://doi.org/10.1111/j.1475-6803.2011.01296.x.

Balsmeier, B., Fleming, L., \& Manso, G. (2017). Independent boards and innovation. Journal of Financial Economics, 123(3), 536557. Available at: https://doi.org/10.1016/j.jfineco.2016.12.005.

Başgoze, P., \& Sayin, C. (2013). The effect of R\&D expenditure (investments) on firm value: Case of Istanbul stock exchange. Journal of Business Economics and Finance, 2(3), 5-12.

Black, F., Jensen, M. C., \& Scholes, M. (1972). The capital asset pricing model: Some empirical tests. Studies in the Theory of Capital Markets, 81(3), 79-121. Available at: https://doi.org/10.2139/ssrn.908569.

Chan, L. K. C., Lakonishok, J., \& Sougiannis, T. (2001). The stock market valuation of research and development expenditures. Journal of Finance, 56(6), 2431-2456. Available at: https://doi.org/10.1111/0022-1082.00411.

Cohen, L., Diether, K., \& Malloy, C. (2013). Misvaluing innovation. The Review of Financial Studies, 26(3), 635-666. Available at: https://doi.org/10.1093/rfs/hhs 183.

Cremers, M. K., Nair, V. B., \& John, K. (2009). Takeovers and the cross-section of returns. Review of Financial Studies, 22(4), 1409-1445. Available at: https://doi.org/10.1093/rfs/hhno32.

Da Silva, R. B., Klotzle, M. C., Pinto, A. C. F., \& Da Motta, L. F. J. (2018). R\&D investment and risk in Brazil. Global Finance Journal, 35, 106-114. Available at: https://doi.org/10.1016/j.gfj.2017.08.003.

Dongmei, L. (2011). Financial constraints, R\&D investment, and stock returns. The Review of Financial Studies, 24(9), $2974-3007$. Available at: https://doi.org/https://doi.org/10.1093/rfs/hhro43.

Duqi, A., Mirti, R., \& Torluccio, G. (2011). An analysis of the R\&D effect on stock returns for European listed firms. European Journal of Scientific Research, 58(4), 482-496.

Fama, E. F., \& French, K. R. (1993). Common risk factors in the returns on stocks and bonds. Journal of Financial Economics, 33(1), 3-56. Available at: https://doi.org/10.1016/0304-405X(93)90023-5. 
Fama, E. F., \& French, K. R. (2015). A five-factor asset pricing model. Journal of Financial Economics, 45(4), 1-22. Available at: https://doi.org/10.2469/dig.v45.n4.1.

Fama, E. F., \& French, K. R. (2008). Average returns, B/M, and share issues. The Journal of Finance, 63(6), 2971-2995. Available at: https://doi.org/10.1111/j.1540-6261.2008.01418.x.

Fama, E. F., \& MacBeth, J. D. (1973). Risk, return, and equilibrium empirical tests. The Journal of Political Economy, 81(3), 607636. Available at: https://doi.org/10.1086/260061.

Franzen, L. A., Rodgers, K. J., \& Simin, T. T. (2007). Measuring distress risk: The effect of R\&D intensity. Journal of Finance, 62(6), 2931-2967. Available at: https://doi.org/10.1111/j.1540-6261.2007.01297.x.

Ghaffar, A., \& Khan, W. A. (2014). Impact of research and development on firm performance. International Journal of Accounting and Financial Reporting, 4(1), 357. Available at: https://doi.org/10.5296/ijafr.v4i1.6087.

Gibbons, M. R., Ross, S. A., \& Shanken, J. (1989). A test of the efficiency of a given portfolio. Econometrica, 57(5), 1121-1152. Available at: https://doi.org/https://www.jstor.org/stable/1913625.

Grabowksi, H. G., \& Mueller, D. (1978). Industrial research and development, intangible capital stocks, and firm profit rates. Bell Journal of Economics, 9(2), 328-343. Available at: https://doi.org/10.2307/3003585.

Gu, L. (2016). Product market competition, R\&D investment, and stock returns. Journal of Financial Economics, 119(2), 441-455. Available at: https://doi.org/10.1016/j.jfineco.2015.09.008.

Kim, Y. S., \& Park, K. J. (2020). R\&D spending and stock returns: Evidence from South Korea. Asian Economic and Financial Review, 1O(7), 744-757. Available at: https://doi.org/10.18488/journal.aefr.2020.107.744.757.

Kundlia, S., \& Verma, D. (2021). Illiquidity premium in the Indian stock market: An empirical atudy. Asian Economic and Financial Review, 11(6), 501-511. Available at: https://doi.org/10.18488/journal.aefr.2021.116.501.511.

Lev, B., Sarath, B., \& Sougiannis, T. (2005). R\&D reporting biases and their consequences. Contemporary Accounting Research, 22(4), 977-1026. Available at: https://doi.org/10.1506/7xmh-qq74-l6gg-cjrx.

Lev, B., \& Sougiannis, T. (1996). The capitalization, amortization, and value-relevance of R\&D. Journal of Accounting and Economics, 21(1), 107-138. Available at: https://doi.org/10.1016/0165-4101(95)00410-6.

Li, D. (2011). Financial constraints, R\&D investment, and stock returns. Review of Financial Studies, 24(9), 2974-3007. Available at: https://doi.org/10.1093/rfs/hhr043.

Lin, J. C., \& Wang, Y. (2016). The R\&D premium and takeover risk. Accounting Review, 91(3), 955-971. Available at: https://doi.org/10.2308/accr-51270.

Lintner, J. (1965). The valuation of risk assets and the selection of risky investments in stock portfolios and capital budgets. The Review of Economics and Statistics, 47(1), 13-37. Available at: https://doi.org/10.2307/1924119.

$\mathrm{Lu}, \mathrm{S}$. (2020). The explanatory power of R\&D for the stock returns in the Chinese equity market. Pacific-Basin Finance Journal, 62, 101380. Available at: https://doi.org/10.1016/j.pacfin.2020.101380.

Majumdar, S. K. (2011). Scalability versus flexibility: Firm size and R\&D in Indian industry. The Journal of Technology Transfer, 36(1), 101-116. Available at: https://doi.org/10.1007/s10961-009-9147-x.

Rubera, G., \& Kirca, A. H. (2012). Firm innovativeness and its performance outcomes: A meta-analytic review and theoretical integration. Journal of Marketing, 76(3), 130-147. Available at: https://doi.org/10.1509/jm.10.0494.

Sharpe, W. F. (1964). Capital asset prices: A theory of market equilibrium under conditions of risk. The Journal of Finance, 19(3), 425-442. Available at: https://doi.org/10.1111/j.1540-6261.1964.tbo2865.x.

Sinha, A. K., Mishra, A. K., \& Patel, Y. (2019). Firm size, R\&D expenditure, and international orientation: An empirical analysis of performance of Indian firms. International Journal of Technological Learning, Innovation and Development, 11(4), $311-$ 336. Available at: https://doi.org/10.1504/ijtlid.2019.10028321.

Sougiannis, T. (1994). The accounting based valuation of corporate R\&D. Accounting Review, 69(1), 44-68.

Sunder, J., Sunder, S. V., \& Zhang, J. (2017). Pilot CEOs and corporate innovation. Journal of Financial Economics, 123(1), 209224. Available at: https://doi.org/10.1016/j.jfineco.2016.11.002. 
Wang, Q., \& Zhang, F. (2020). Does increasing investment in research and development promote economic growth decoupling from carbon emission growth? An empirical analysis of BRICS countries. Journal of Cleaner Production, $252,119853$. Available at: https://doi.org/10.1016/j.jclepro.2019.119853.

Warusawitharana, M. (2015). Research and development, profits, and firm value: A structural estimation. Quantitative Economics, 6(2), 531-565. Available at: https://doi.org/10.3982/qe282.

Xu, M., \& Zhang, C. (2004). The explanatory power of R\&D for the cross-section of stock returns: Japan 1985-2000. Pacific Basin Finance Journal, 12(3), 245-269. Available at: https://doi.org/10.1016/j.pacfin.2003.09.001.

Yu, L., Liu, X., Fung, H. G., \& Leung, W. K. (2020). Size and value effects in high-tech industries: The role of R\&D investment. North American Journal of Economics and Finance, 51(10), 1-12. Available at: https://doi.org/10.1016/j.najef.2018.10.001.

Yury, D., Albert, L., \& Ilia, K. (2017). R \& D effects, risks and strategic decisions: Evidence from listed firms in R \& D- intensive countries. Foresight - The Journal of Future Studies, Strategic Thinking and Policy, 19(3), 615-627. Available at: https://doi.org/https://doi.org/10.1108/FS-07-2017-0033.

Views and opinions expressed in this article are the views and opinions of the author(s), Asian Economic and Financial Review shall not be responsible or answerable for any loss, damage or liability etc. caused in relation to/arising out of the use of the content. 